\title{
A Study on Railway Signal System to Apply CDMA-QAM Method
}

\author{
Hiroshi Mochizuki Student Member (Nihon University, mochi@bit.ecs.cst.nihon-u.ac.jp) \\ Akira Asano Non-member (Kyosan Electric Mfg Co, Ltd.) \\ Minoru Sano Member (Kyosan Electric Mfg Co, Ltd.) \\ Sei Takahashi Member (Nihon University) \\ Hideo Nakamura Member (Nihon University)
}

Keywords: QAM, CDMA, railway signal system, track circuit, synchronous acquisition

Recently, QAM (Quadrature Amplitude Modulation) is paid to attention in digital modulation method, and it has been used for wireless LAN and digital broadcasting. QAM is a modulation method that puts information on carrier amplitude and phase.So QAM can achieve high-capacity data transmission that the use efficiency of frequency band is good. But QAM has a bad characteristic that is weak to the noise and the interference because distance between each symbol is short. On the other hand, CDMA (Code Division Multiple Access) can transmit two or more signals to the same frequency band, and this can be achieved by spread spectrum (SS). Moreover, because this is good also in the characteristic to noise, this is a technique widely used.

Then we propose the method that not transmission data but CDMA signal, obtained after transmission data is modulated by spread code and multiplexed, is given to each symbol of QAM. Figure 1 shows Block diagram of CDMA-QAM method. According to this figure, in transmitter, the transmission data of the serial is converted into parallel data of the number of multiple-access. After that, this data is modulated by spread codes. And, when the number of multiple-access is 63 , because 64 values from 0 to 63 are taken as amplitude of CDMA since each channel is added, this is allocated in each symbol of 64QAM. In receiver, received signal is first

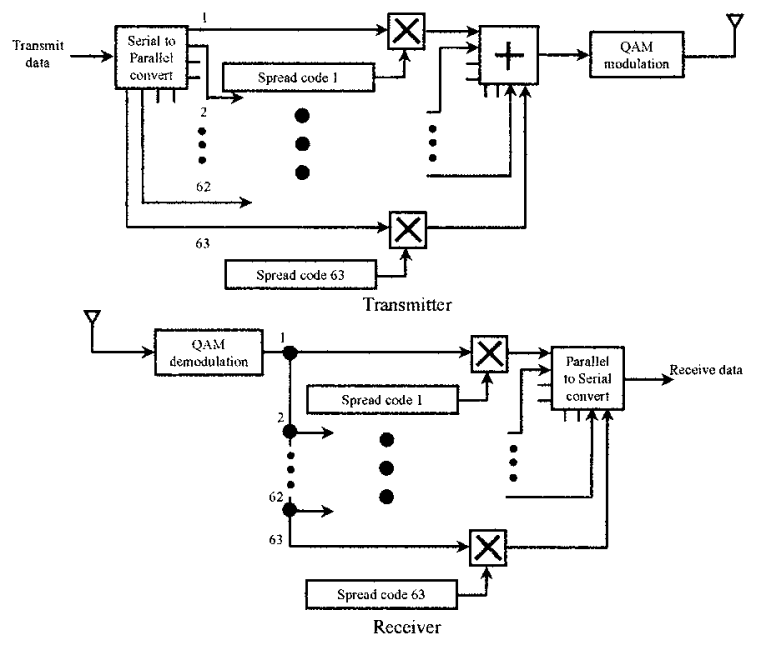

Fig. 1. Block diagram of CDMA-QAM method demodulated by QAM, this is demodulated by spread codes afterwards. Here, because not transmission data but amplitude of CDMA is allocated in each symbol of 64QAM in this method, if it is possible to recover by demodulation using spread codes even if there is an error in the symbol of QAM, it is possible to transmit correctly without mistaking the transmission data. In addition, when a highorder bit is allocated in I channel and the low-order bit is allocated in Q channel, because the influence that I channel has on BER characteristic is large, the constellation map of QAM is made the one that amplitude of I channel was enlarged more than that of Q channel.

Basing on above, we studied about railway signal system on track circuit as a sample to apply this method, we named it CDMA-QAM rail transmission system. Figure 2 shows BER characteristic as the result of computer simulations. According to this figure, we verified that BER characteristic is able to be improved as the amplitude of I channel enlarged more compared with that of Q channel.

In addition,we studied about the method of a synchronous acquisition. As the result of computer simulations, we established a good method by giving the same data for a synchronous acquisition to some channels.

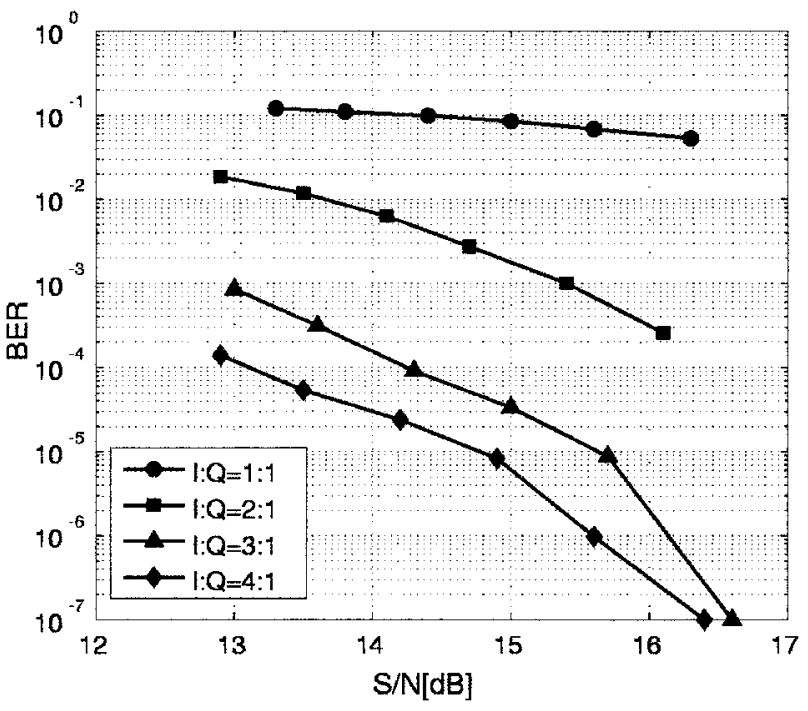

Fig. 2. BER characteristic of CDMA-QAM rail transmission system 


\title{
CDMA-QAM方式の鉄道信号システムへの適用に関する一検討
}

$\begin{array}{ccccc}\text { 学生員 } & \text { 望月 } & \text { 寛* } & \text { 非会員 浅野 } & \text { 晃** } \\ \text { 正 員 佐野 } & \text { 実** }^{*} & \text { 正 員 高橋 } & \text { 聖* } \\ \text { 正 員 中村 } & \text { 英夫* } & & & \end{array}$

\author{
A Study on Railway Signal System to Apply CDMA-QAM Method \\ Hiroshi Mochizuki*, Student Member, Akira Asano**, Non-member, Minoru Sano**, Member, \\ Sei Takahashi*, Member, Hideo Nakamura*, Member
}

\begin{abstract}
Recently, QAM (Quadrature Amplitude Modulation) transmission is paid to attention in digital modulation method, and it has been used for wireless LAN and digital broadcasting. QAM is a modulation method that puts information on carrier amplitude and phase. So QAM can achieve high-capacity data transmission that the use efficiency of frequency band is good. But QAM has a bad characteristic that is weak to the noise and the interference because distance between each symbol is short. Then we propose the method that not transmission data but CDMA signal, obtained after transmission data is modulated by spread code and multiplexed, is given to each symbol of QAM. And we studied about railway signal system on track circuit as a sample to apply this method. As result of computer simulations, we verified to be able to achieve the improvement of signal to noise ratio by optimizing the constellation map of QAM. We report with the method of a synchronous acquisition.
\end{abstract}

キーワード：QAM, CDMA, 鉄道信号システム, 軌道回路，同期捕捉

Keywords: QAM, CDMA, railway signal system, track circuit, synchronous acquisition

\section{1. まえがき}

近年，列車制御の更なる高度化を目的として，軌道回路 を用いた鉄道信号システムの多情報化が注目されている。 軌道回路は無線方式などと比べて，情報のセキュリティ確 保や意図的な外乱対策などシステムの安全性確保への配慮 が比較的容易にとれるといった利点を持ち，また，レール という既存のインフラを用いるため, 増設する設備が比較 的軽微であるというコスト面での優位性も持っている。た た，軌道回路を伝送媒体として考えた時，それが持つ電気 車雑音や狭帯域特性など，一般の通信と比べて極めて劣悪 な環境下にあり多情報化への妨げとなっている。

今回，この問題に対して筆者らは，搬送波の位相と振幅 の両方を用いて情報伝送を行う変調方式として，現在，無 線 LAN やデジタル放送などで広く用いられている QAM

\footnotetext{
* 日本大学大学院理工学研究科

干 274-8501 船橋市習志野台 7-24-1

Graduate School of Science and Technology, Nihon University

7-24-1, Narashinodai, Funabashi 274-8501

** 京三製作所

干 230-0031 横浜市鶴見区平安町 2-29-1

Kyosan Electric Mfg Co, Ltd.

2-29-1, Heian-cho, Tsurumi, Yokohama 230-0031
}

（Quadrature Amplitude Modulation：直交振幅変調）に注目 する。この QAM については，実際によく用いられている 16QAM を例にすると, 1 シンボルの伝送で 4 ビットのデー 夕伝送を実現することができるため，単位周波数あたりの 利用効率が良いという利点を持っている。しかし, 各シン ボル間の距離が短いため, その他のデジタル変調方式と比 べ, 雑音や干渉に弱いという久点も持っているため, その 実用範囲は，SN 比が比較的高い環境下での使用に限られ ているのが現状である。

一方, CDMA (Code Division Multiple Access : 符号分 割多元接続) は, スペクトラム拡散 (Spread Spectrum : 以 下 SS）通信技術により実現可能な多元接続方式であり，具 体的には，互いに直交な拡散符号を用いることにより，各 チャネル間で干渉なくデータ伝送を行うことが可能で，か つ，その受信は拡散符号の相関処理により実現されている ため，耐雑音性に優れた手法である。

今回，筆者らは QAM の各シンボルに従来の送信データ そのものを割り当てるのではなく, 送信データを SS 通信 技術によって拡散変調し多元化したCDMA 信号を割り当 てる方式（以下 CDMA-QAM 方式）を提案する。本方式 では, QAMでのシンボル誤りがあった時に, CDMAの相 関処理により，それを吸収することが目的で，結果として， 
QAM の SN 比特性の向上が期待できる。また, 本方式で は, CDMA の多元接続数によらず単一の QAM 変復調器の みで構成可能なため, 大幅な回路削減が実現可能であると いう利点も有している。

以上，筆者らが提案する CDMA-QAM 方式について，そ の最適シンボル配置を検討するとともに，軌道回路を用い た鉄道信号システムへ適用した時の性能評価を，計算機シ ミュレーションにより行う。

さらに, CDMA で重要となるシステムの同期捕捉手法に ついては，CDMAの幾つかのチャネルに同期捕捉用データ を与えて実現する手法について提案し，その性能について も評価する。

\section{QAM の原理}

QAM とは，振幅変調と位相変調の両方を組み合わせた変 調方式であり, 今, 搬送波周波数を $f_{c}[\mathrm{~Hz}]$ とした時, QAM 信号 $s(t)$ は以下の (1) 式で表わされる。

$$
s(t)=a_{I}(t) \cos \left(2 \pi f_{c} t\right)+a_{Q}(t) \sin \left(2 \pi f_{c} t\right)
$$

このように，位相が $\pi / 2 \operatorname{rad}$ 異なるような直交する二つの

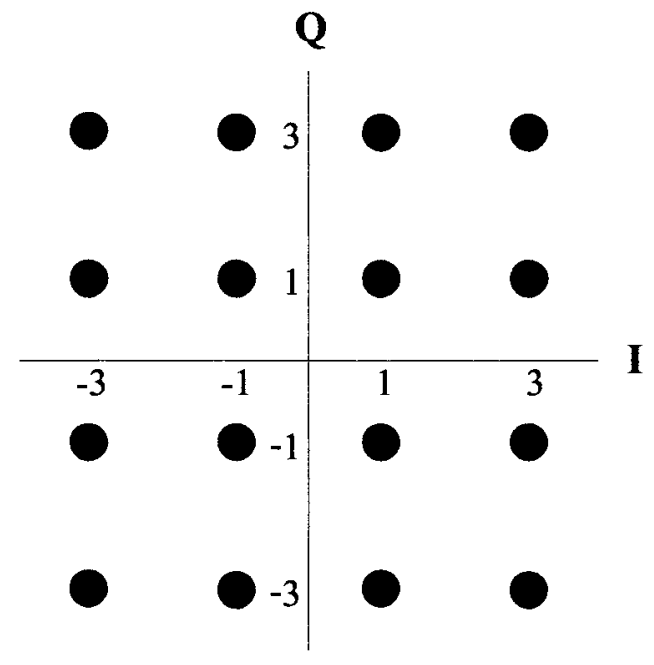

図 1 16QAM のシンボル配置

Fig. 1. Constellations of 16QAM.
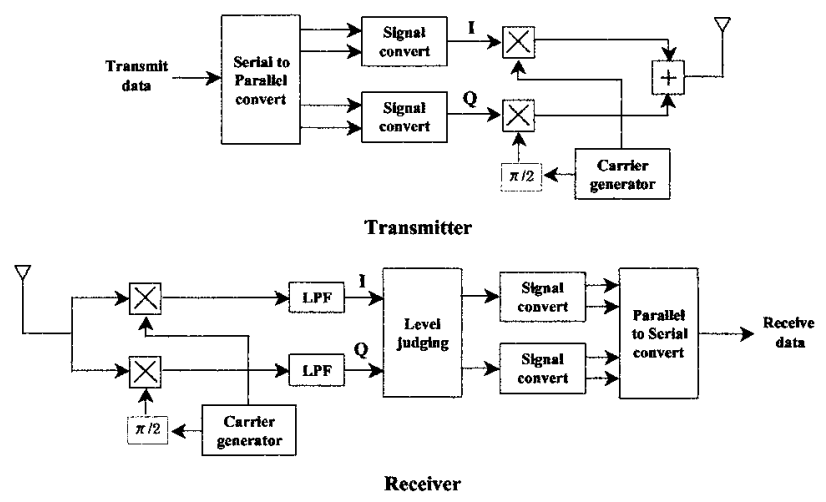

図 2 16QAM のブロック図

Fig. 2. Block diagram of 16QAM.
搬送波 $\cos \left(2 \pi f_{c} t\right)$ 及び $\sin \left(2 \pi f_{c} t\right)$ を用い，また， $a_{I}(t)$ 及び $a_{Q}(t)$ に送信データに応じた振幅を与える。この振幅に与え るビット数に応じて，16QAM，64QAM，256QAM な゙が 存在する。図 1 は 16QAM におけるシンボル配置の一例で ある。図 1 では, I チャネル, Qチャネル共にシンボルを等 間隔となるように配置した例である。このように, 16QAM の各シンボルは I チャネルと Q チャネルそれぞれ 4 值の組 み合わせにより決定され, 結果として, 4 ビットを 1 シン ボルとしてデータ伝送することが可能である。

図 2 は，実際，16QAM による伝送を行う時のブロック 図である。図 2 より，送信機では，4 ビットデータをシリ アルーパラレル変換し, 上位 2 ビット及び下位 2 ビットと いったような 2 組に分割して，それぞれをIチャネル及び $\mathrm{Q}$ チャネルに与える。その後, 信号変換回路により, 各チャ ネルでベースバンド信号を生成し, 直交変調を行い送信す る。一方, 受信機では, 各チャネルで復調し LPFを通した 信号を 4 值に判定した後， 2 ビットデータに変換し，それ らをパラレルーシリアル変換によって結合し, 受信データ を得ることができる。

\section{CDMA-QAM 方式の概要}

〈3・1〉 CDMA CDMA は多元接続の一種であり， $\mathrm{SS}$ 通信技術を用いることにより実現できる。図 3 は，一般 的に良く用いられているDS (Direct Sequence：直接拡散) 方式のブロック図である。本方式では，送信機でまず搬送 波による狭帯域変調を行う。その後, 拡散符号による拡散 変調を行うことにより，信号のスペクトラムを広帯域に拡 散する。一方, 受信機では, 受信した広带域信号に送信機 との符号同期を取った上で逆拡散を行うことにより，元の 狭帯域信号に戻し，搬送波による復調を経てデータを得る ような構成となっている。

ここで, 図 3 中の拡散符号について, もし, 選択した複

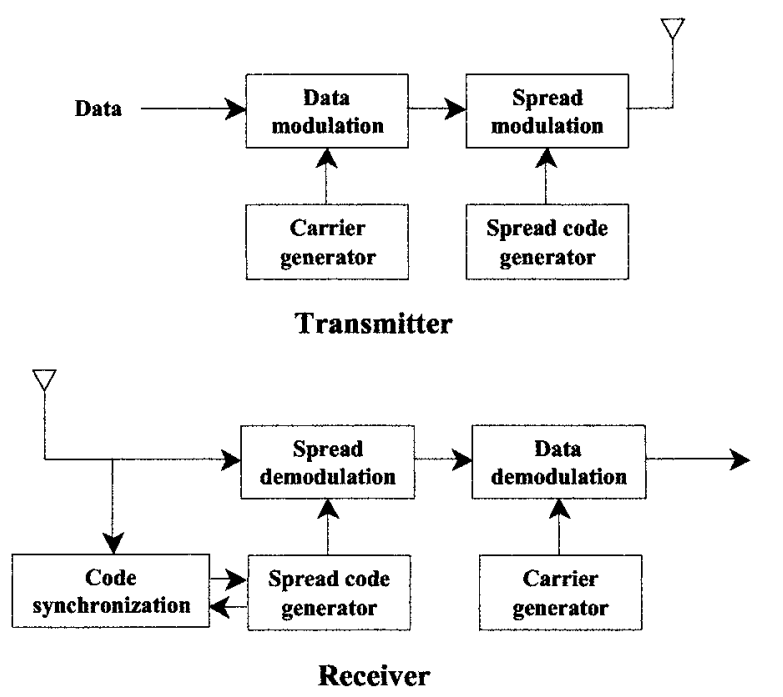

図 $3 \mathrm{SS}$ 通信のブロック図 (DS 方式)

Fig. 3. Block diagram of SS communication (DS system). 
数の拡散符号間で，相互相関特性が十分に小さければ，こ れらのチャネルは同一周波数帯で多元化しても干渉するこ となくデータを伝送することが可能である。これをCDMA と呼ぶ。

実際，CDMAの実現については，拡散符号として直交符 号が採用されている方式がある。この符号は，以下の (2) 式 に示すアダマール行列により生成される。

$$
\begin{aligned}
H_{1} & =[1] \\
H_{N} & =\left[\begin{array}{ll}
H_{N-1} & H_{N-1} \\
H_{N-1} & -H_{N-1}
\end{array}\right] .
\end{aligned}
$$

この (2) 式によって生成された行列の各行が直交符号とし て用いられる。今，符号長 32 の直交符号 32 個について, 任意の自己相関及び相互相関特性を図 4 及び図 5 に示す。 これらの図より，この符号の特徴としては，任意の符号位 相差における自己相関及び相互相関特性は CDMA の拡散 符号としてょく用いられている $\mathrm{M}$ 系列や Gold 符号に比べ 悪い特性となるが，同期確立時における任意の符号間の相 互相関特性が全てゼロとなり極めて良好な特性になるとい う特徵を持っている。また，符号数については符号長の数 だけあるので，全てのチャネルを同期して送信する同期式 CDMA という条件下で, 多元接続により一般のデジタル変 調と比較して情報速度の飛躍的向上を望める ${ }^{(1)}$ 。

$\langle\mathbf{3} \cdot 2\rangle$ CDMA-QAM 方式の基本構成 今回, 筆者ら が提案する CDMA-QAM 方式のブロック図を図 6 に示す。

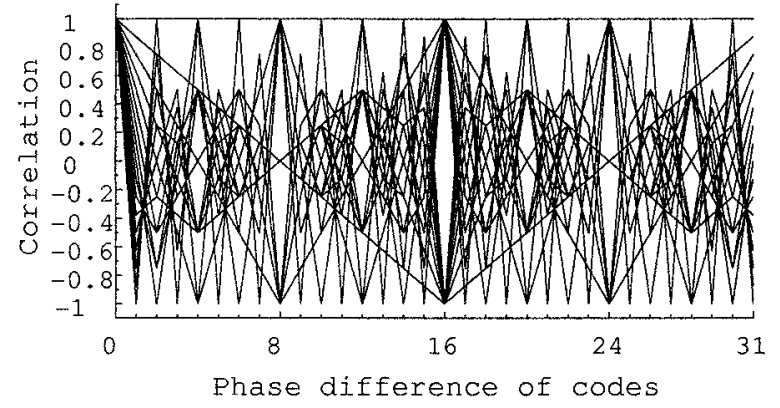

図 4 符号長 32 の直交符号の自己相関特性

Fig. 4. Auto-correlation characteristics of length 32 orthogonal code.

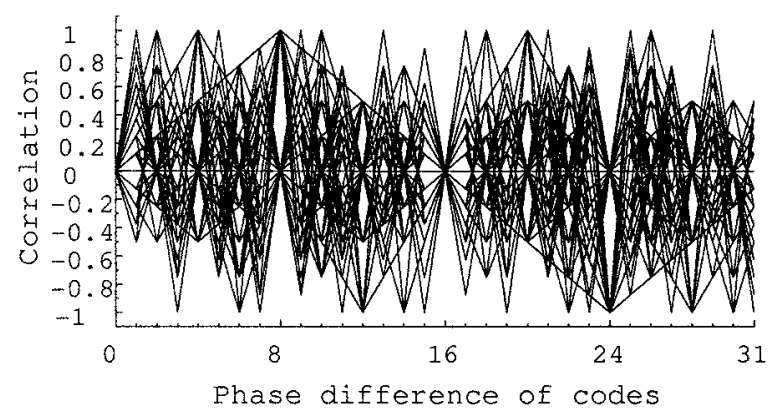

図 5 符号長 32 の直交符号の相互相関特性

Fig. 5. Cross-correlation characteristics of length 32 orthogonal code.
図 3 で示した SS 通信のブロック図とは異なり，送信部で は，63のパラレルデータに変換された送信データは，まず， 拡散符号によって拡散変調される。そして, 各チャネルを 足し合わせた結果，振幅值として 0〜63 までの 64 值をと り得るので，これを 2 進数表現した時の上位 3 ビットを I チャネル, 下位 3 ビットを $\mathrm{Q}$ チャネルとして, 図 7 のよう に64QAM の各シンボルに割り当て, 送信信号とする。受 信部でも, まず, 64QAM の復調を行った後, 拡散符号に より逆拡散を行い, パラレルーシリアル变換して受信データ とする。

この方式では，64QAM の各シンボルに割り当てられて いるのは，送信データでなく拡散変調によって多元化され た CDMA 信号であるので，仮に受信部での QAM 復調時 にシンボルを誤ったとしても, CDMAの逆拡散処理によっ

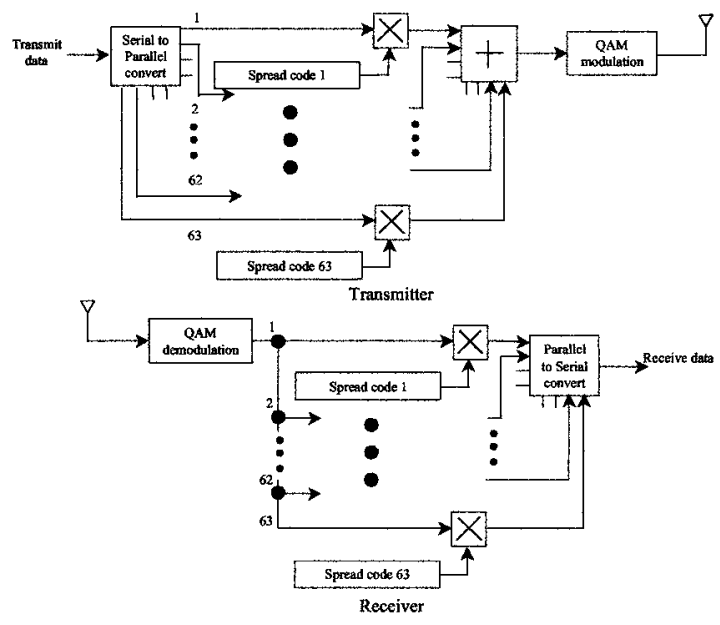

図 6 CDMA-QAM 方式のブロック図

Fig. 6. Block diagram of CDMA-QAM method.

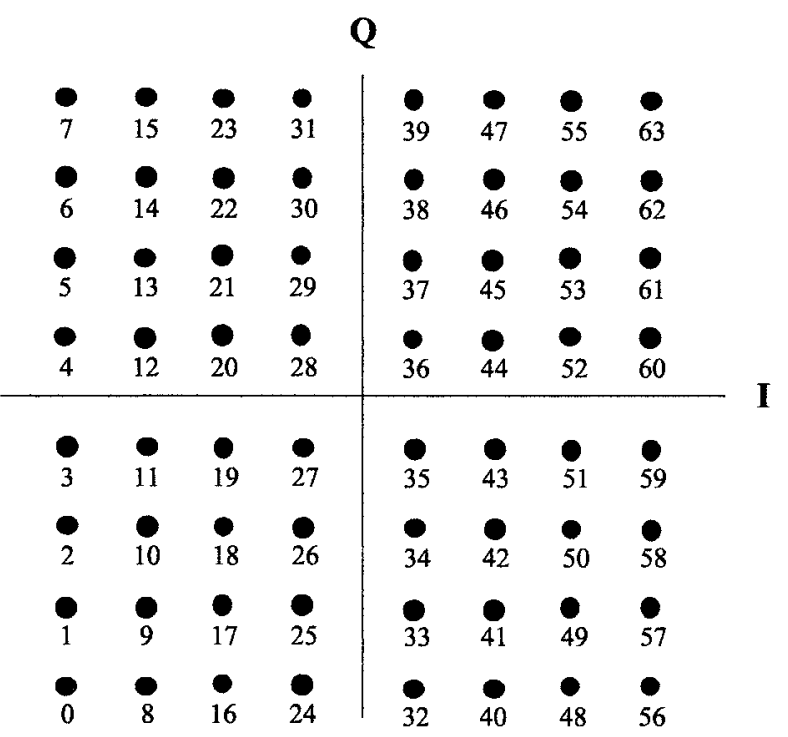

図 7 CDMA-QAM 方式における各シンボルの 振幅データ割り当て

Fig. 7. Amplitude data allocation of each symbol in CDMA-QAM method. 
て吸収できる範囲内であれば，送信デー夕は誤りなく受信 できるという特徴を持っている。また，伝送対象として 1 対 1 を想定した時, 図 3 の構成では, 搬送波による変復調 器が多元接続数だけ必要になるのに対して, 図 6 の構成で は，多元接続数によらず QAM の变復調器が 1 つだけあれ ば良いため，大幅な回路削減を実現することもできる。

〈3・3〉 CDMA-QAM 方式のシンボル配置 CDMAQAM 方式のシンボル配置を決定するにあたり，まず，送信 部に扔いて拡散変調後, 各チャネルを足し合わせた時の振 幅值について解析を行う。その頻度分布を図 8 に示す。こ

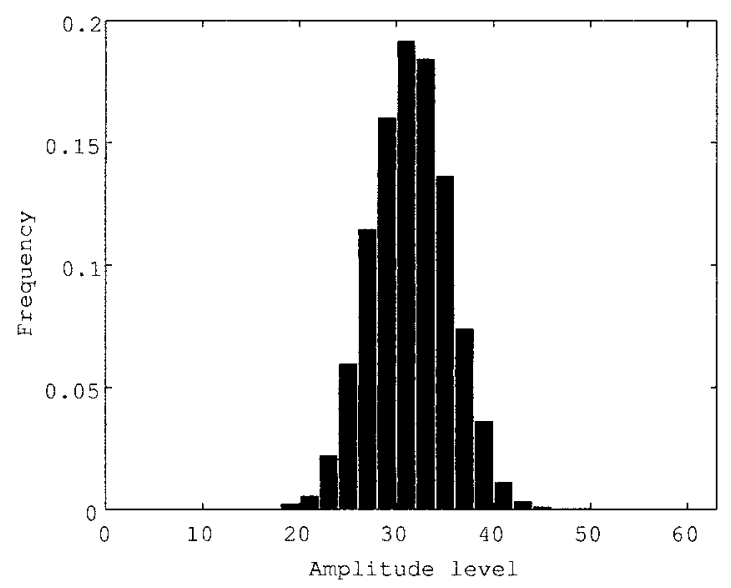

困 8 拡散変調後の振幅值の頻度分布

Fig. 8. Frequency distribution of amplitude after spread modulation.

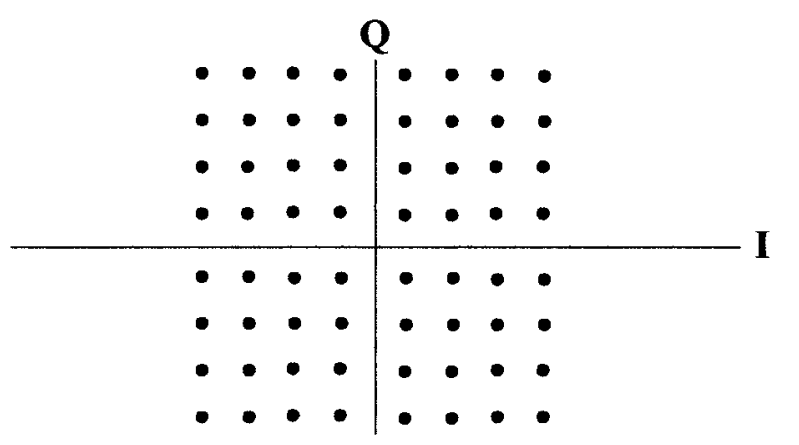

\section{I:Q=1:1}

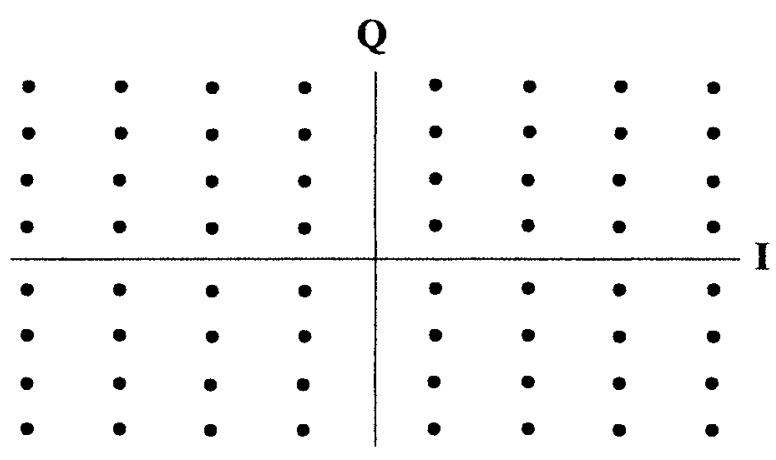

$\mathrm{I}: \mathbf{Q}=\mathbf{2}: \mathbf{1}$

図 9 CDMA-QAM 方式のシンボル配置

Fig. 9. Constellations of CDMA-QAM method.
こで，筆者らが提案する CDMA-QAM 方式の多元接続数 を 63 とすると, 振幅值として取り得る值は, 先ほども述べ たように0６3の 64 值である。それを踏まえると図 8 よ り, 振幅值は最大值のほほ半分となる 32 を中とした不 均一な分布になっていることが分かる。

以上のことょり，QAMのシンボル配置について検討す

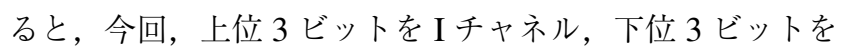
Qチャネルとして各シンボルに図 7 のように割り当ててい るので, 図 8 のような不均一な分布の時, $\mathrm{Q}$ 軸付近のシン ボルに集中する。一方で，Iチャネルは上位ビットを割り当 てている。具体的には，Qチャネル側へ 1 シンボル誤った 時には，振幅值の変動分が 1 であるのに対して，Iチャネル 側へ 1 シンボル誤った場合には振幅值の変動分が 8 と大き くなる。そのため, I チャネルは Q チャネルに比べてシス テム全体のビット誤り率特性に与える影響が大きい。した がって, QAMのシンボル配置として図 9 のように, Iチャ

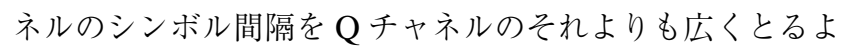
うな配置とすることにより, システム全体の電力を極端に 大きくすることなく, ビット誤り率特性を向上させること ができると考えられる。

\section{4. 鉄道信号システムへの適用}

$\langle\mathbf{4} \cdot \mathbf{1}\rangle$ 背 景 新幹線のブレーキ扱いの効率化や 乗り心地向上を意図したデジタル ATC (Automatic Train Control）の実用化, さらには, 在来線での無線による列車 制御システム ATACS (Advanced Train Administration and Communications System）の実験など，近年，列車制御の高 度化を目的とした取り組みがなされている(2)(3)。しかし実際 は, 情報速度という点でまだ十分でない。例えば，デジタル

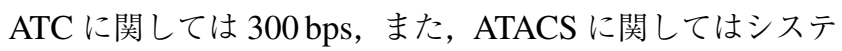
ム全体としては $9600 \mathrm{bps}$ であるものの，それを制御対象列 車数で分割するため 1 列車あたりの情報速度は大きくない のが現状である。そこで, 筆者らは提案した CDMA-QAM 方式について，軌道回路を伝送媒体とした鉄道信号システ ム (以下 CDMA-QAM 式レール伝送システム) への適用を 行い, 既存技術の情報速度よりも十分に大きい $2000 \mathrm{bps}$ 程 度の情報速度の実現可能性について検討する。

〈4・2 $\rangle$ レールを用いたデータ伝送の特徵 今回, 伝 送媒体として軌道回路を用いるが，これは送電線路や通信 線路と同じように図 10 のような分布定数回路として考え ることができる。ここで $R$ をレール抵抗， $L$ をレールイン

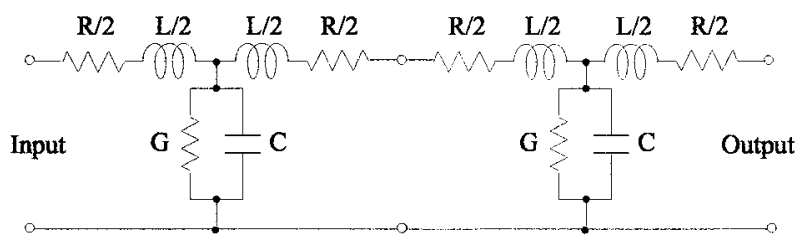

図 10 軌道回路の等価回路

Fig. 10. Equivalent circuit of track circuit. 

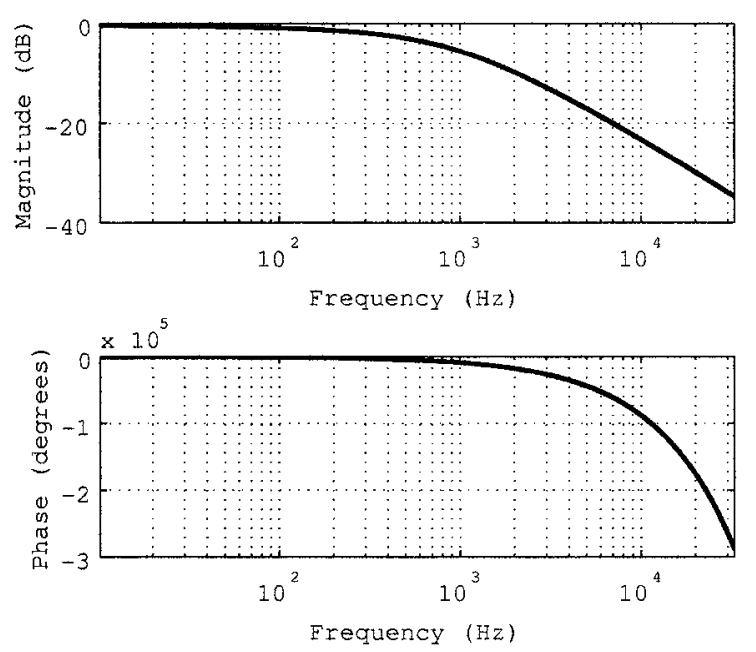

図 11 軌道回路の周波数特性

Fig. 11. Frequency response of track circuit.

ダクタンス, $G$ を漏れコンダクタンス,$C$ を静電容量と呼 び，これらは軌道回路定数と呼ばれている。実際の軌道回 路は数 $100 \mathrm{~m}$ から $1 \mathrm{~km}$ 程度の長さでその周波数特性は数 $\mathrm{kHz}$ 程度で大きく減衰する低周波通過特性を持っている。 したがって，一般の通信系と異なり高周波を使うことができ ないという特徵を持っている(4)。今回の計算機シミュレー ションにおいては，文献(5)に基づいた軌道回路の代表的 な特性をデジタルフィルタで表現し，検討を行うこととす る。図 11 に周波数特性を示す。

また，電気車雑音に関して，今回対象として考えている 直流電化区間においては, 一般の通信系の白色雑音とは異 なり，電源周波数の 6 次高調波である $300 \mathrm{~Hz}$ 周期で大き なピークを持つような特性を有しており，さらに時間的変 動も大きいという特徴も持っている。なお, 本研究での計 算機シミュレーションによる評価については, 直流電化区 間で実際に測定されたデータを用いている。

このように，レールを用いたデータ伝送では，低周波通 過特性に起因して情報速度を大きく取れないことや電気車 雑音への配慮が必要といった固有の問題がある。

しかし, ATC システムに代表される列車制御というフェー ルセーフ性が要求されるシステムへの適用においては，情 報のセキュリティ確保や意図的な外乱対策などシステムの 安全性確保への配慮が比較的容易にとれるといった利点も 持っている。また，新たな設備を増設する必要性もないの で，コスト面でも有利である。

今回，筆者らが提案する CDMA-QAM 式レール伝送シ ステムにおいては，現行のデジタル ATC と同じ構成を取 り，送受信部における変調方式を変更しているだけである ため, 現行と同等のフェールセーフ性を有している。また, 異なる軌道回路からの信号の回りこみなどに対しても，明 確に弁別できる必要があると考えており，これについては， 同期をずらしたり拡散符号の選択に配慮したりするといっ た対応法が考えられる。さらに, CDMAにおける拡散変調
表 1 CDMA-QAM 式レール伝送システムの仕様

Table 1. Specification of CDMA-QAM rail transmission system.

\begin{tabular}{|l|l|}
\hline Parameter & Values \\
\hline Carrier frequency & $4096 \mathrm{~Hz}$ \\
\hline Spread code & $\begin{array}{l}\text { The code that takes exclusive-OR of } \\
\text { orthogonal code and the sequence that } \\
\text { added M sequence to "1" as balance chip }\end{array}$ \\
\hline Code length & 64 \\
\hline The number of multiple access & 63 \\
\hline $\begin{array}{l}\text { Transmission speed for each } \\
\text { channel }\end{array}$ & $32 \mathrm{bps}$ \\
\hline Total transmission speed & $2016 \mathrm{bps}$ \\
\hline Track circuit length & $1 \mathrm{~km}$ \\
\hline Rail noise & Measured data \\
\hline
\end{tabular}

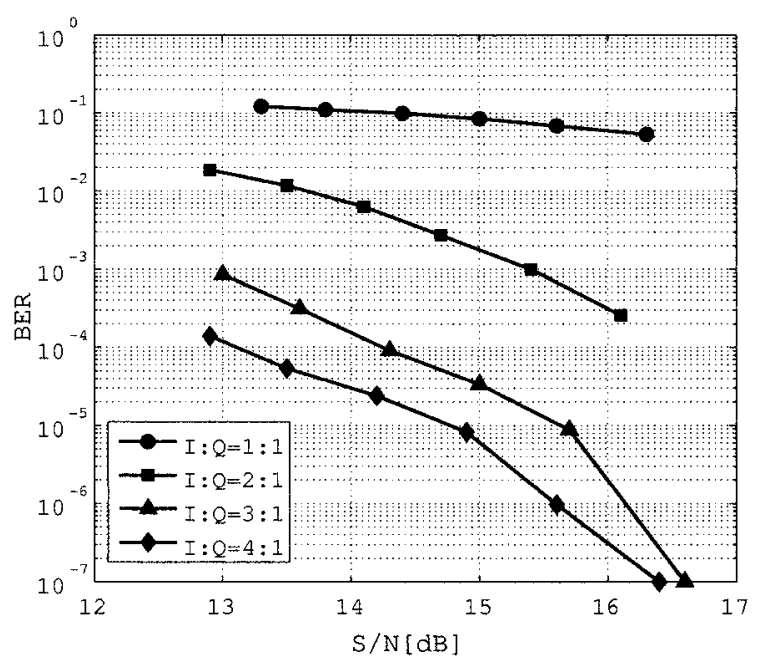

図 12 CDMA-QAM 式レール伝送システムの ビット誤り率特性

Fig. 12. BER characteristic of CDMA-QAM rail transmission system.

は, 多重化の他に, 実データに対して拡散符号による一種 の暗号化を施している側面も合わせ持っているため, 情報 のセキュリティ確保や意図的な外乱対策という点では, 現 行方式より優れた特性を有している。

そして，本システムで実現した情報量の増加は，指令情 報の伝達や在来線では踏切制御状況に関する情報の伝達と いった, 現在システムの枠外とされている機能を取りこめ る他, 旅客案内などのサービス情報の提供といった機能拡 充にも利用できると考えられる。

〈4·3〉 性能評価 CDMA-QAM 式レール伝送システ ムの仕様を表 1 に示す。ここで, 表 1 の拡散符号について は, 拡散変調時のスペクトラムを効率的に拡散させること を目的として，直交符号と 64 チップ目に 1 を加えた M 系 列との排他的論理和をとった符号を採用する。軌道回路長 に関しては図 11 に示した軌道回路の周波数特性を算出す る際に用い, また, 電気車雑音は直流電化区間で実際に測 定されたデー夕を用い, その雑音レベルを変動させて, 計 算機シミュレーションに反映させている。 
この仕様に基づいて, 計算機シミュレーションによる性 能評価を行った。I チャネルと Q チャネルとのシンボル間 隔比を $1: 1$ から $4: 1$ まで変化させた時の SN 比に対する ビット誤り率特性を図 12 に示す。図 12 より，シンボル間 隔比を大きくするにつれて，ビット誤り率特性が向上して いることが分かり，その比が $3: 1$ 及び $4: 1$ の時，鉄道通 信の基準である $10^{-5}$ のビット誤り率( () を得られることが 分かり，筆者らが提案したCDMA-QAM 方式に扔けるシ ンボル配置の有効性が検証された。

また，受信信号と実際のシンボルとのずれを評価するた めに EVM（Error Vector Magnitude）を導入する。具体的 には，受信信号より得られたシンボルのIチャネル成分及

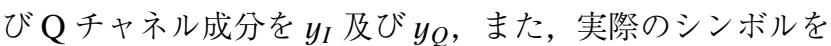
$a_{I}$ 及び $a_{Q}$ とする時, EVM を以下に示す 2 つの式で定義 する。

$$
\bar{e}_{I}=\frac{1}{n} \sum_{m=1}^{n}\left|y_{I, m}-a_{I, m}\right|
$$

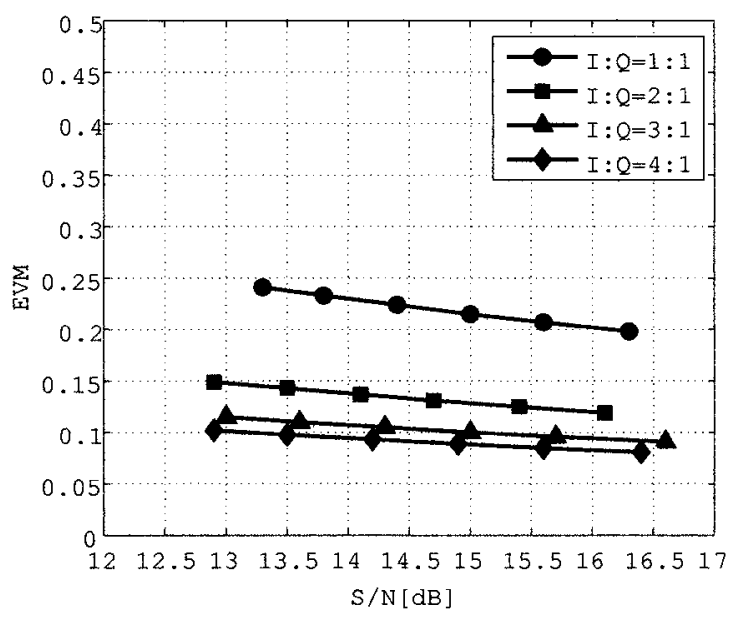

図 13 EVM 特性（Iチャネル）

Fig. 13. EVM characteristic (I channel).

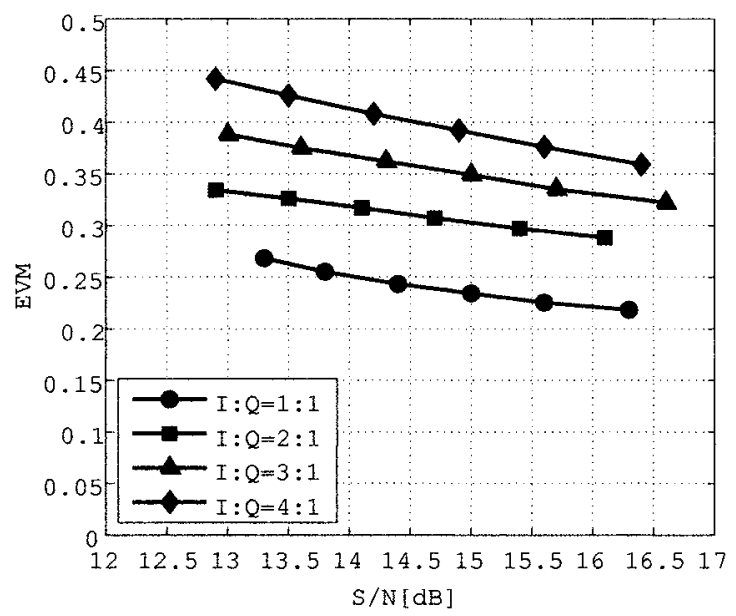

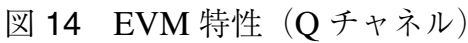

Fig. 14. EVM characteristic (Q channel).

$$
\bar{e}_{Q}=\frac{1}{n} \sum_{m=1}^{n}\left|y_{Q, m}-a_{Q, m}\right|
$$

(3) 式及び (4) 式より得られた EVM 特性を I チャネルは 図 13，Qチャネルは図 14 にそれぞれ示す。これらの図よ り, シンボル間隔比が大きくなるにつれて, I チャネル及

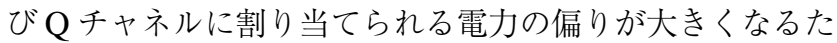
め, Qチャネルに関しては EVM 特性が悪くなっているが, ビット誤り率特性に大きな影響を与える Iチャネルに関し ては，その特性が改善されていることが分かる。

\section{5. 同期捕捉手法}

ここでは, CDMA-QAM 方式の同期捕捉手法について検 討する。図 6 に示したCDMA-QAM 方式のブロック図中 の受信部に打いて, 各チャネルでの拡散符号による逆拡散 の結果として得られる出力は, 自己相関值と相互相関值と の和である。そこで，図 15 のように，63 チャネルで得ら れる全出力の絶対值の和を符号長と同じ長さ 64 のシフトレ ジジスタへ符号位相差毎に順次加算していく。そして，こ れをある一定のサイクル数分だけ繰り返し，シフトレジス 夕内の最大值を検出して，それを同期捕捉点とする。

図 15 の構成で得られるシフトレジスト出力を図 16 に示 す。図 16 より, 符号位相差がゼロの同期捕捉点で出力が最 大となっているが, その他, 同期捕捉点でない任意の符号 位相差で一様に出力が大きくなってしまうため, 通信系の 雑音などによって，同期捕捉を誤ってしまう可能性がある。

そこで，筆者らは送信側であらかじめCDMA の幾つか のチャネルに同期捕捉用データとして同じデータを与え， 受信側でそれらのチャネルに関してデータ判定を行い，全 てのデータが一致した時のみ，63 チャネルで得られる全出 力の絶対值の和をシフトレジジスタへ加算する手法を提案 する。これを，一致判定ゲートを加えた同期捕捉部と呼び， そのブロック図を図 17 に示す。そして，図 17 の構成で得 られる, シフトレジスト出力を図 18 に示す。図 18 より,

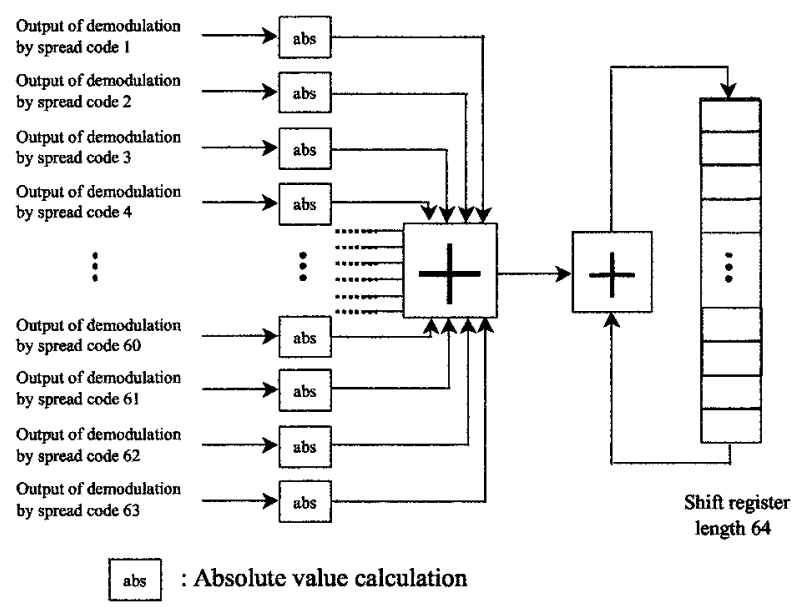

図 15 同期捕捉部のブロック図

Fig. 15. Block diagram of synchronous acquisition part. 


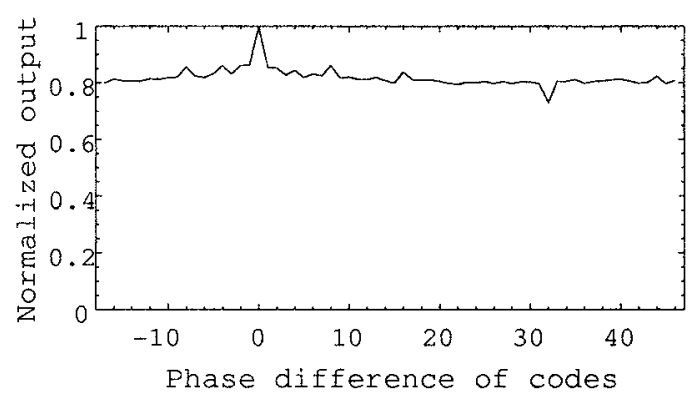

図 16 同期捕捉部での符号位相差対出力特性

Fig. 16. Output characteristic to phase difference of codes in synchronous acquisition part.

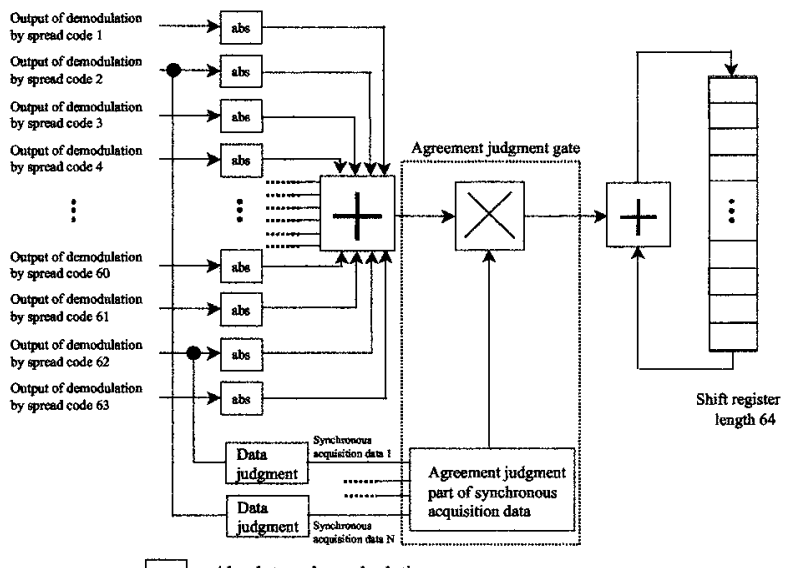

: Absolute value calculation

図 17 一致判定ゲートを加えた同期捕捉部の ブロック四

Fig. 17. Block diagram of synchronous acquisition part that added agreement judgment gate.

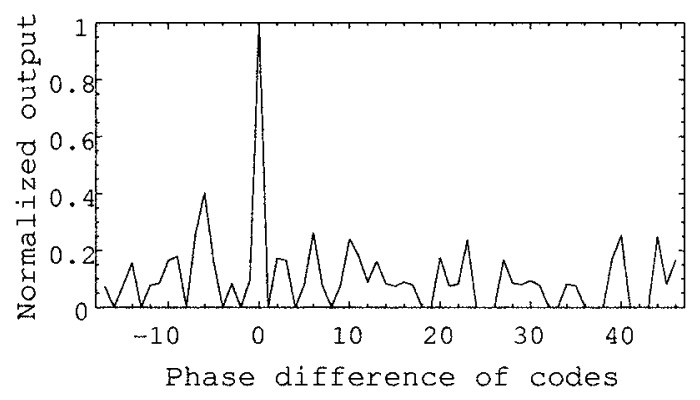

図 18 一致判定ゲートを加えた同期捕捉部での 符号位相差対出力特性

Fig. 18. Output characteristic to phase difference of codes in synchronous acquisition part that added agreement judgment gate.

符号位相差がゼロの同期捕捉点で出力が最大となっている 点は前に示した図 16 と同じであるが，その他，同期捕捉点 でない任意の符号位相差で一様に出力が小さく抑えること ができ，結果として，耐雑音性の向上を図れ，良好な同期 捕捉を行えることが分かる。

\section{6. むすび}

今回，QAM におけるビット誤り率特性の向上を目的と して，筆者らは，各シンボルに割り当てるデー夕について， 従来の送信デー夕そのものではなく, 送信デー夕を SS 通 信技術によって拡散变調し多元化したCDMA 信号を割り 当てた方式であるCDMA-QAM 方式について提案し，その 最適なシンボル配置も含めて検討を行った。そこで, 2 進 数表現された振幅值の上位 3 ビットを I チャネル, 下位 3

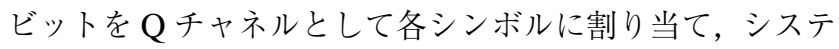
ム全体のビット誤り率特性に与える影響が大きいIチャネ ルのシンボル間隔を Qチャネルのそれよりも広くとるよう な配置とした。これにより，ビット誤り率特性を向上でき るだけでなく, CDMA における拡散変調後の振幅值の頻度 分布が不均一で $\mathrm{Q}$ 軸付近のシンボルに集中するため, シス テム全体の電力が極端に大きくならないことも示した。

そして，このCDMA-QAM 方式の適用例として，軌道回 路を伝送媒体とした鉄道信号システムを挙げ, CDMA-QAM 式レール伝送システムについて性能評価を行った。

その結果，代表的な軌道回路特性と実際に計測された電 気車雑音を取り入れた計算機シミュレーションにより，I チャネルのシンボル間隔を大きくするようなるシンボル配 置でのビット誤り率特性の向上を確認し, 実用化への見通 しを検証した。

さらに, CDMA-QAM 方式の同期捕捉手法については, 各チャネルでの拡散符号による逆拡散の結果として得られ る出力の絶対值の和をシフトレジジスタへ符号位相差毎に 順次加算していく手法に加え, 筆者らは, 送信側で CDMA の幾つかのチャネルに同期捕捉用データとして同じデー夕 を与え，それらを受信側で一致判定し，全てのデータが一 致した時のみ，63 チャネルで得られる全出力の絶対值の和 をシフトレジジスタへ加算する一致判定ゲートを加えた手 法を提案し, 結果として, 耐雑音性の向上を図れ, 良好な 同期捕捉が行えることを確認した。

現在までに，今回の提案手法の送受信部を構成し，実際 に伝送路を用いて計算機シミュレーションの成果の確認を 行っている。今後は, CDMA-QAM 方式におけるシンボル 配置などの深度化を図ると共に, 実際の軌道回路, 電気車 雑音の下で安定稼動できることの検証を行いたい。

(平成 17 年 6 月 28 日受付, 平成 17 年 10 月 3 日再受付)

$$
\text { 文献 }
$$

(1) H. Harada and R. Prasad: Simulation and Software Radio for Mobile Communications, Artech House (2002)

(2) S. Irie and T. Hasegawa: "A study on the Railway Signalling System using Spread Spectrum Communication", IEICE Technical Report, Vol.93, No.89, pp.43-48 (1993-6) (in Japanese)

入江章二・長谷川孝明：「鉄道信号へのスペクトル拡散通信の適用 に関する一検討」, 信学技報, Vol.93, No.89, pp.43-48 (1993-6)

（3） ATACS システム評価委員会：「ATACS システム評価委員会 報告 書」, 日本鉄道電気技術協会 (2005)

(4) 電気鉄道における教育調査専門委員会：最新鉄道電気工学, コロナ 社 (2000) 
（5）信号保安協会：鉄道信号ハンドブック，信号保安協会 (1969)

（6）渡辺郁夫・高重哲夫：「ディジタル ATC の情報伝送」, 日本鉄道電気 技術協会, 鉄道と電気技術, Vol.6, No.2, pp.10-14 (1995-2)

望月寞 (学生員) 1978 年 10 月 16 日生。 2001 年日大・

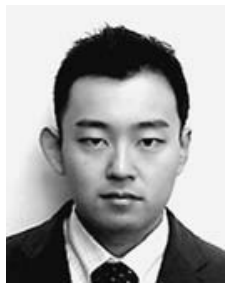
理工・電子工学卒。2003 年同大学院博士前期課程 電子工学専攻了。現在，同大学院博士後期課程電 子工学専攻在学中。鉄道信号システムに関する研 究に従事。電子情報通信学会学生会員。

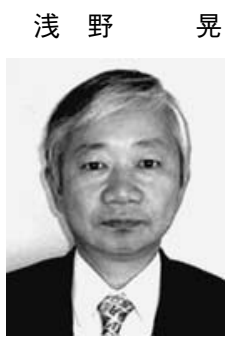

(非会員) 1957 年 5 月 7 日生。 1981 年東京電機 大・工・電気工学卒。現在，(株）京三製作所に勤 務。鉄道信号システムの開発に従事。

佐 野

実（正員） 1962 年 8 月 28 日生。1986 年東京電機 大・理工・電気工学卒。現在，(株) 京三製作所信 号事業部信号技術部システムグループ課長。列車 制御のシステム設計に従事。
聖 （正員） 1968 年 8 月 18 日生。1991 年日大・理

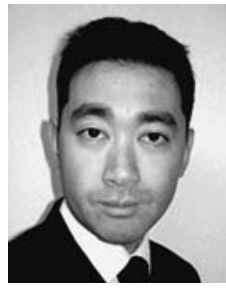
工・建築卒。1993 年同大学院博士前期課程建築学 専攻了。現在, 同大電子情報工学科専任講師。博 士 (工学)。鉄道信号システム, ソフトコンピュー ティングの産業応用に関する研究に従事。電子 情報通信学会, 日本信頼性学会, 日本建築学会各 会員。

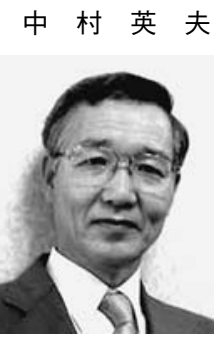

（正員） 1948 年 7 月 12 日生。1971 年国鉄中央鉄 道学園大·電気卒。1972 年鉄道技術研究所, 1978 年日大·委託研究員, 1986 年東京理科大 $·$ 工 II · 電気卒，1990 年鉄道総合技術研究所室長， 1990 年同退職，日大・理工助教授，現在，同大教授。 博士 (工学)。ディペンダブルシステム，情報応 用交通工学の研究に従事。電子情報通信学会 DC 研究専門委員会委員, 信頼性学会会長, 電気学会 論文委員。電子情報通信学会, 日本信頼性学会, 安全工学会, IEEE 各 会員。

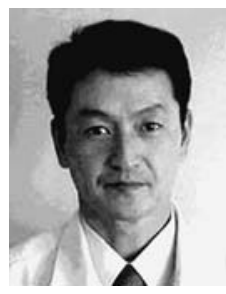

